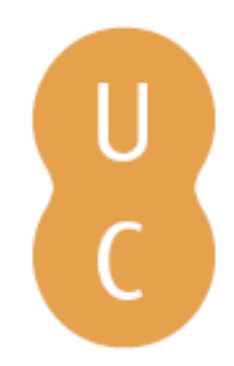

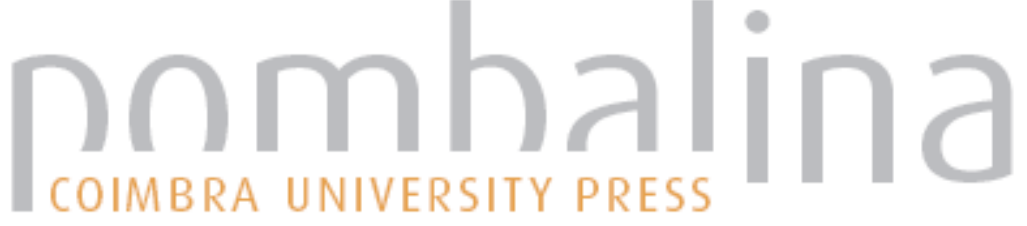

A representação de navios em mosaicos luso-romanos

Autor(es): Mantas, Vasco Gil

Publicado por: Imprensa da Universidade de Coimbra

URL

persistente: URI:http://hdl.handle.net/10316.2/38355

DOI: $\quad$ DOI:http://dx.doi.org/10.14195/978-989-26-0438-1_16

Accessed : $\quad$ 26-Apr-2023 05:28:49

A navegação consulta e descarregamento dos títulos inseridos nas Bibliotecas Digitais UC Digitalis, UC Pombalina e UC Impactum, pressupõem a aceitação plena e sem reservas dos Termos e Condições de Uso destas Bibliotecas Digitais, disponíveis em https://digitalis.uc.pt/pt-pt/termos.

Conforme exposto nos referidos Termos e Condições de Uso, o descarregamento de títulos de acesso restrito requer uma licença válida de autorização devendo o utilizador aceder ao(s) documento(s) a partir de um endereço de IP da instituição detentora da supramencionada licença.

Ao utilizador é apenas permitido o descarregamento para uso pessoal, pelo que o emprego do(s) título(s) descarregado(s) para outro fim, designadamente comercial, carece de autorização do respetivo autor ou editor da obra.

Na medida em que todas as obras da UC Digitalis se encontram protegidas pelo Código do Direito de Autor e Direitos Conexos e demais legislação aplicável, toda a cópia, parcial ou total, deste documento, nos casos em que é legalmente admitida, deverá conter ou fazer-se acompanhar por este aviso.

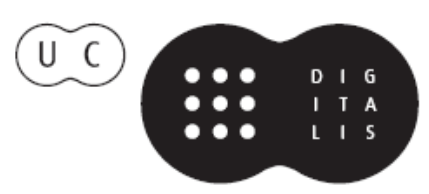


Francisco de Oliveira

Pascal Thiercy

Raquel Vilaça

Coordenação

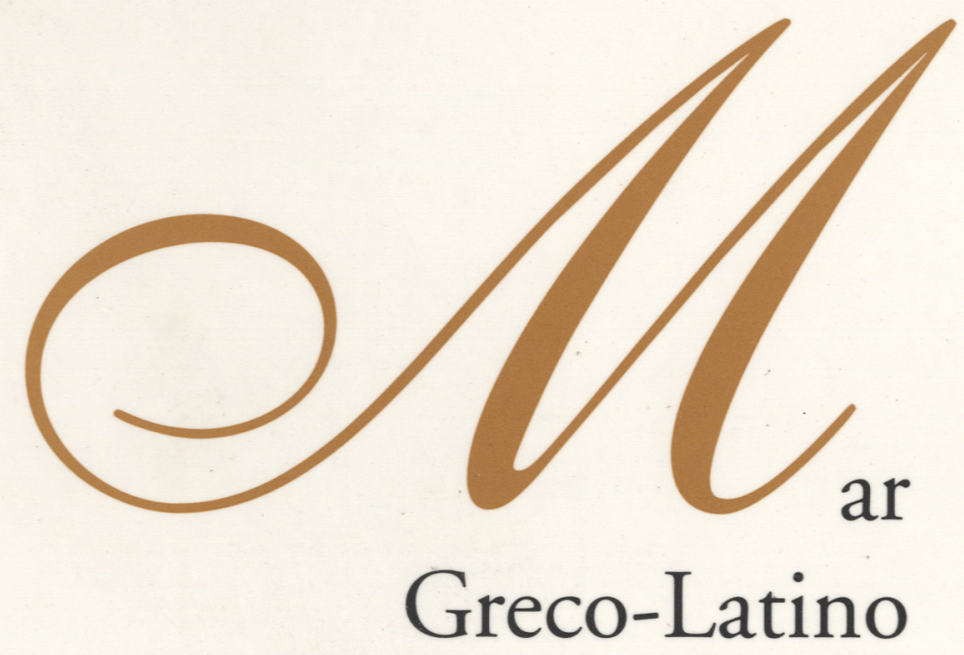

- colmbra 2006 


\title{
A REPRESENTAÇÃO DE NAVIOS EM MOSAICOS LUSO-ROMANOS
}

\author{
Vasco Gil Mantas \\ Universidade de Coimbra
}

O estudo do mar na Antiguidade Clássica sofreu longamente o efeito da falta de conhecimentos geradora de preconceitos que o tornaram, até há bem pouco tempo, difícil de abordar e frequentemente considerado como uma área de importância secundária, sobretudo em relação à Civilização Romana. É certo que o mar está presente na poesia e na literatura latinas, não faltando trabalhos sobre esta temática, mas a verdade é que muitos dos mal entendidos que se desenvolveram sobre o mar romano resultaram directamente de considerações mais ou menos retóricas elaboradas pelos próprios Romanos ${ }^{(1)}$. Durante muito tempo ficou de lado a apreciação do que foi o mar como espaço geoestratégico, desde o início da expansão na Itália até ao ocaso da grandeza imperial, aquele mar utilizado por Lucrécio como símbolo contrário a uma vida sem perigos, mas que é o mesmo, afinal, que a truculência de Trimalcião enfrentou com navios de velas desfraldadas ${ }^{(2)}$. O Império, alargado significativamente às margens atlânticas, teve no mar um

\footnotetext{
(1) A avaliação negativa das viagens marítimas encontra-se presente em topoi literários, a considerar exactamente como tal. Entre muitos exemplos possíveis recordamos apenas dois, bem conhecidos: Horácio, Epist., I, 11, 28; Plínio-o-Antigo, N.H., XIX, 5-7. Agradecemos cordialmente a preparação das figuras desta comunicação ao Dr. Luís Madeira. Fontes abreviadas no texto: Corpus Inscriptionum Latinarum, Berlim $(=C I L)$; J. d'Encarnação, Inscrições romanas do conventus pacensis, Coimbra, $1984(=I R C P)$.

${ }^{(2)}$ Lucrécio, De Rer. Nat., II, 1-54; Petrónio, Sat., 71.
} 
espaço privilegiado de circulação de pessoas, bens e ideias, garante da unidade na diversidade e instrumento essencial de uma estrutura económica de tipo orgânico. Estudar o mar romano consiste, portanto, em estudar um elemento essencial da Civilização Romana ${ }^{(3)}$.

A feliz realização deste Congresso no âmbito de mais uma Semana da Universidade, oportunamente subordinada este ano ao tema do mar, permite apreender a grande variedade de assuntos que com ele se relacionam, enquadrando-se da melhor forma no que devem ser as preocupações da Universidade na defesa e promoção de um património cultural e histórico particularmente importante num país como Portugal, em tempos pioneiro nas aventuras marítimas e na construção de um mundo verdadeiramente global. Para que a vocação marítima portuguesa não se perca e para que a nossa presença no mar não retroceda a níveis exíguos ou dispensáveis, é preciso conjugação de esforços, não apenas simbólicos e inconsequente, mas criadores de uma dinâmica que salvaguarde uma posição digna de um passado que não pode resumir-se a simples memória. Numa obra de SaintExupéry, seguramente menos lida que outras, este autor distingue entre os povos que se limitam a pescar e outros que lançam navios ao mar para conquistar o mundo ${ }^{(4)}$. Portugal deve manter-se no segundo destes grupos, não já pela força militar, naturalmente, mas por toda uma série de actividades científicas, culturais e económicas que estão perfeitamente ao nosso alcance e nas quais a Universidade deve exercer uma função primordial.

A iconografia de navios antigos foi, durante séculos, o suporte das interpretações e das tentativas de reconstrução visual dos mesmos, conduzindo com muita frequência a representações impressionantes pela evidente impossibilidade de que algum dia tais navios pudessem ter navegado (Fig.1). Estas dificuldades resultavam directamente quer da falta de restos de navios antigos

\footnotetext{
(3) J. Rougé, La marine dans l'Antiquité, Paris, 1975, p.17-27; M. Grant, The Ancient Mediterranean, Nova Iorque, 1988, p.298-302.

(4) A. de Saint-Exupéry, A cidadela, Lisboa, 1996, p.326.
} 


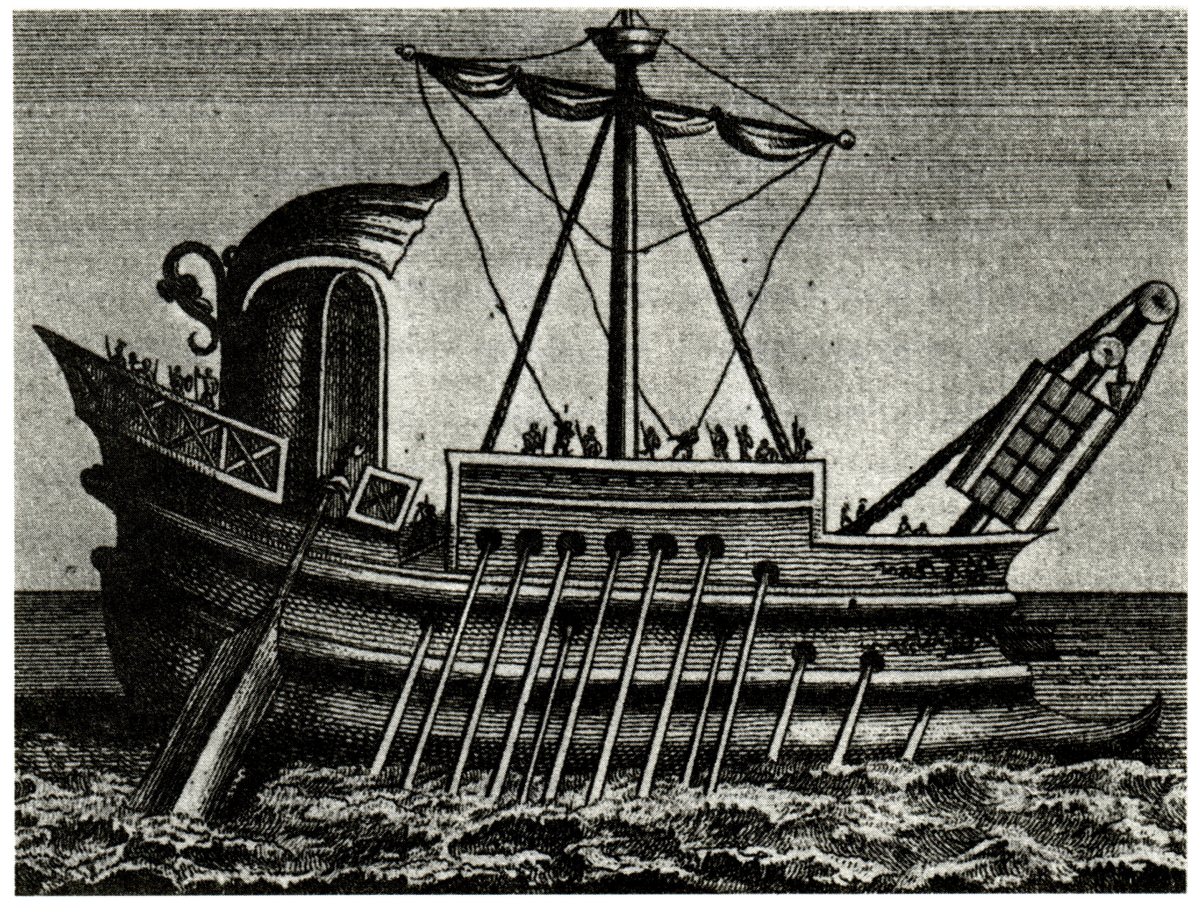

Fig. 1 - Gravura de Humblot (século XVII) representando um navio romano do período das Guerras Púnicas.

estudados, quer da copiosa existência de fontes iconográficas de fraca qualidade, indutoras de erros quando se pretendia recriar uma representação fiável dos navios da Antiguidade Clássica, nomeadamente da época romana ${ }^{(5)}$. Pela mesma razão muitas passagens da literatura greco-latina relacionadas com a tecnologia naval permaneciam obscuras ou eram mal interpretadas, contribuindo para uma situação de incerteza que desencorajava os investigadores. Esta quase total dependência de fontes indirectas durou praticamente até ao século XX, quando a recuperação dos navios do Lago Nemi, em 1922, permitiu estudar em boas condições as técnicas de construção naval romana, abrindo caminho à compreensão das mesmas, e depois que a Arqueologia

\footnotetext{
(5) As dificuldades sentidas pelos investigadores e o tipo de informação que podiam produzir tais fontes encontram-se exemplarmente demonstradas em duas obras que durante muito tempo foram de referência obrigatória: C. Torr, Navis, "Dictionnaire des Antiquités Grecques et Romaines", IV, Paris, 1877, p.24-40; H. Leclercq, Navigation, Navire, "Dictionnaire d'Archéologie Chrétienne et de Liturgie", CXXXII-CXXXIII, Paris, 1935, col.972-1019.
} 
Subaquática foi dotada, a partir de 1942, de um instrumento fundamental sob a forma do escafandro autónomo aperfeiçoado por Gagnan e Cousteau ${ }^{(6)}$, o que permitiu rapidamente localizar e estudar muitas centenas de navios antigos naufragados, sobretudo no Mediterrâneo ${ }^{(7)}$, ainda que quase todos comerciais. Esta referência ilustra claramente uma situação que continua a limitar o conhecimento actual dos navios da Antiguidade e a causar dúvidas justificadas e acesas polémicas quando se trata de reconstituir os navios de guerra ${ }^{(8)}$.

Entre as diversas fontes iconográficas susceptíveis de facultar informações sobre os navios romanos, os mosaicos ocupam um lugar particularmente importante, pelo seu razoável número e por, devido às suas dimensões, poderem mostrar pormenores que outras representações mais reduzidas dificilmente suportariam. É certo que a qualidades dos mosaicos não é alheia ao seu valor como fonte informativa, existindo significativas diferenças na representação de navios, como imediatamente se deduz da comparação, por exemplo, entre os numerosos navios configurados de forma fruste nos pavimentos do chamado Forum das Corporações, em Óstia, e aquele que um excelente mosaico conservado no Museu do Capitólio, em Roma (Fig.2), parcialmente representa(9). Por outro lado, as representações de navios são, com muita frequência, estilizadas, consistindo em interpretações artísticas sumárias, que se limitam a figurar os elementos essenciais da imagem comum de uma embarcação, reproduzindo modelos cujo arquétipo se desconhece ou que foi sendo modificado ao longo do tempo. Os chamados mosaicos nilóticos são um bom exemplo desta circunstância ${ }^{(10)}$.

(6) G. Ucelli, Le navi di Nemi, Roma, 1950; G. F. Bass, Arqueologia subaquática, Lisboa, 1969, p.28.

(7) A. J. Parker, Ancient shipwrecks of the Mediterranean and the roman provinces, Oxford, 1992. Nesta obra acham-se referenciados 1259 naufrágios.

(8) Consultar, para uma rápida ideia geral da evolução verificada: Marine antique, "Dossiers d'Archéologie", 183, 1993; V. Mantas, Tecnologia naval romana, "Memórias da Academia de Marinha", XXV, 1995, (X), p.37-44.

(9) G. Becatti, Scavi di Ostia, IV, Mosaici e pavimenti marmorei, Roma, 1961, p.345-348, tav. CLXXV-CLXXXIV; P. Pomey (Dir.), La navigation dans l'Antiquité, Aix-en-Provence, 1997, p.84.

(10) Os mosaicos nilóticos, de que o de Palestrina é, justamente, o mais famoso, divulgaram-se largamente no mundo romano, assim como as pinturas de idêntico tema, onde constituíram moda entre o século I a. C. e o século III, subsistindo em determinados ambientes até ao século VI. 


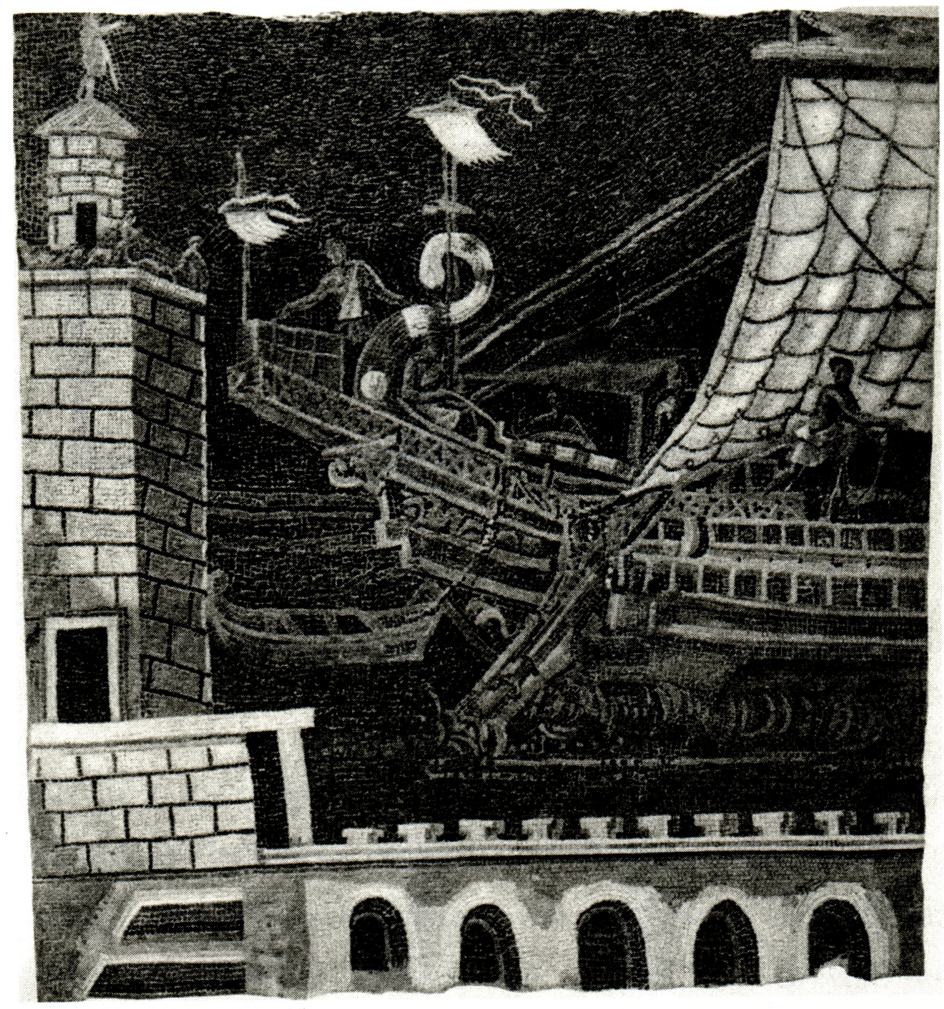

Fig. 2 - Mosaico representando instalações portuárias

e a popa de um navio comercial romano (Museu do Capitólio, Roma).

Alguns mosaicos procuram associar às figuras legendas identificando a tipologia dos navios e embarcações representadas, com uma declarada finalidade pedagógica, também existente a nível literário ${ }^{(11)}$. O caso mais conhecido desta situação é o famoso mosaico dos navios (Fig.3), escavado nos finais do século XIX nas ruínas de uma casa de Althiburus (Henchir-Medeina), na actual Tunísia. O referido mosaico representa um numeroso grupo de

Sobre o mosaico de Palestrina, inspirador de muitos outros: G. Gullini, I mosaici di Palestrina, Roma, 1956; H. Lavagne, La mosaïque du Nil à Préneste, "Les Dossiers d'Archéologie", 201, 1995, p. 66-67.

(11) M. Rodríguez-Pantoja, En torno al vocabulario marino en Latin: los catalogos de naves, "Habis", 6, 1975, p.135-152. 


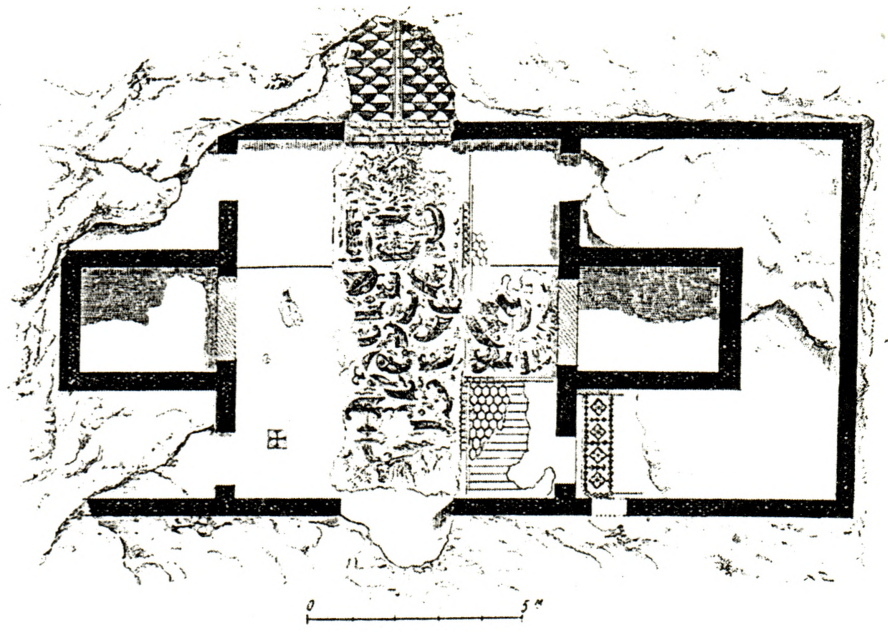

Fig. 3 - O mosaico de Althiburus (Henchir-Medeina), segundo P. Gauckler.

embarcações, num total de 25 , sem respeito pelas proporções entre elas e entre as diversas partes de cada uma, procurando antes de mais destacar de forma convencional o que permite caracterizá-las. Embora o mosaico possa datar-se de finais do século II, as figuras terão sido extraídas de um manual náutico dos finais da República ou inícios do Império $^{(12)}$. É um excelente exemplo deste tipo de iconografia, abundante no Norte de África, onde o recurso à temática marítima foi particularmente numeroso, atingindo por vezes notável qualidade.

A presença, nos mosaicos, de navios ou de animais marinhos, menos neste caso, costuma relacionar-se com a proximidade do mar ou como um índice de relações económicas ou de alguma outra forma de ligação com actividades marítimas, da mesma maneira que se destaca uma distribuição específica algo parecida para os mosaicos de temática literária ou, de alguma forma, marcadamente cultural, como Janine Lancha defende em relação à Península

\footnotetext{
(12) P. Gauckler, Un catalogue figuré de la batellerie greco-romaine. La mosaïque d'Altbiburus, "Memoires et Monuments Piot", XII, 1905, p.113-154; M. P. Duval, La forme des navires romains d'après la mosaïque d'Althiburus, "Mélanges de l’École Française de Rome ", LXI, 1949, p.119-149.
} 
Ibérica $^{(13)}$. Esta ideia, apoiada na carta de repartição dos mosaicos conhecidos, corresponde nas suas grandes linhas, a uma realidade, mas deve ser considerada com alguma cautela, pois nem sempre assim acontece. A perplexidade que Gauckler experimentou face ao mosaico de Altbiburus, alheio a qualquer contexto geográfico marítimo, obrigaria a imaginar alguma explicação complicada para a presença do excelente mosaico da villa de Vega Baja de Toledo, no centro da Península Ibérica e que é, até hoje, o melhor exemplo de um mosaico de temática marítima na Hispânia ${ }^{(14)}$. O facto de ter pertencido a uma fonte monumental talvez ajude a refrear a imaginação dos arqueólogos e historiadores de arte quando procuram explicações condicionadas por análises à margem da mentalidade antiga, complicando o que, muitas vezes, não é difícil de interpretar se não fosse a preocupação em reconstituir uma história que nunca existiu ${ }^{(15)}$. Em qualquer circunstância, o contexto em que se inserem os mosaicos, a todos os níveis, não pode ser esquecido e, de maneira alguma, pode ser reduzido aos seus elementos sociais ou económicos.

A província lusitana, pela sua situação geográfica e forte dependência de relações marítimas, de cabotagem ou de longo curso, para mais facilmente contactar com as áreas centrais do Império, relações imprescindíveis no tocante à exportação dos minérios e dos preparados piscícolas ${ }^{(16)}$, entre outros, deveria contar com maior número de mosaicos com referências claramente marítimas, através da representação de temas ligados ao mar. São, sobretudo, particularmente raras as representações de navios (Fig.4), que apenas se registaram em Mérida e nas villae de Santa Vitória do Ameixial

\footnotetext{
(13) J. Lancha, Mosaïque et culture dans l'Occident romain, Roma, 1997, p.393 (=Lancha, Mosaique).

(14) J. M. Blázquez, Corpus de Mosaicos de España, V, Mosaicos romanos de la Real Academia de Historia, Ciudad Real, Toledo, Madrid y Cuenca, Madrid, 1982, p.33-36, lâm. 16-19.

(15) Blázquez, p.34. A representação de temas marítimos foi largamente utilizada em ambientes aquáticos, em especial em fontes, instalações termais e tanques de peristilos.

(16) J. Alarcão, A produção e a circulação dos produtos, "Nova História de Portugal", I, Lisboa, 1990, p.409-411.
} 
(Estremoz) e de Milreu (Faro). É realmente muito pouco para uma província tão dependente, sob vários aspectos, entre os quais o económico, do uso regular do mar como meio de comunicação. Todavia, não consideremos esta pouca representatividade dos mosaicos como mais uma prova da inexistência ou mediocridade das actividades marítimas lusitanas, pois mesmo em grandes centros portuários peninsulares, como já tivemos oportunidade de referir, os testemunhos dessas actividades são relativamente raros, quando não quase inexistentes $^{(17)}$.

Como explicar esta circunstância ? Cremos que ela pode reflectir, mais uma vez, quer o estado actual da investigação arqueológica, o que o grande número de mosaicos referenciados parece contrariar, quer um traço cultural

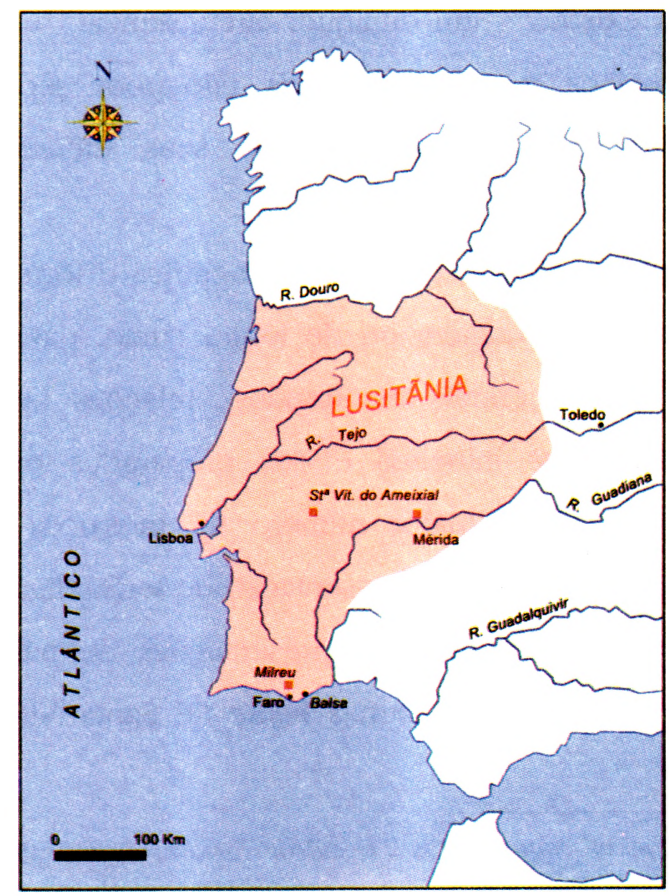

Fig. 4 - Localização dos mosaicos com representação de navios na Lusitânia.

\footnotetext{
(17) V. Mantas, Navegação, economia e relações interprovinciais. Lusitânia e Bética, "Humanitas", L, 1998, p.201-204 (=Mantas, Navegação).
} 
característico da mentalidade das élites peninsulares. Não esqueçamos, também, que dos principais centros marítimos lusitanos poucos mosaicos conhecemos, o que obriga a considerar o facto de possuirmos uma amostra reduzida e parcial do que um dia existiu. Ainda assim, na Lusitânia parece ter havido maior interesse pela fauna e pelas alegorias marinhas do que pela representação de navios, que ocorre de forma secundária, nunca como elemento principal da iconografia. Teria sido muito interessante escavar a totalidade do edifício ossonobense onde se encontrou o célebre mosaico de Oceano, excelente exemplo das alegorias que referimos, tanto mais que nele se representa claramente o Atlântico ${ }^{(18)}$, facto que o insere num ambiente muito especial, que é o das cidades marítimas do Golfo de Cádis. Como o edifício em causa parece corresponder à schola dos naviculários locais, segundo julgamos ${ }^{(19)}$, seria de esperar que outros mosaicos, caso existissem, pudessem mostrar temas marítimos ou, mesmo, navios, como na vizinha villa de Milreu (Fig.5). Infelizmente, não foi possível alargar a escavação de forma a, pelo menos, tentar recuperar a planta de um edifício a todos os títulos invulgar.

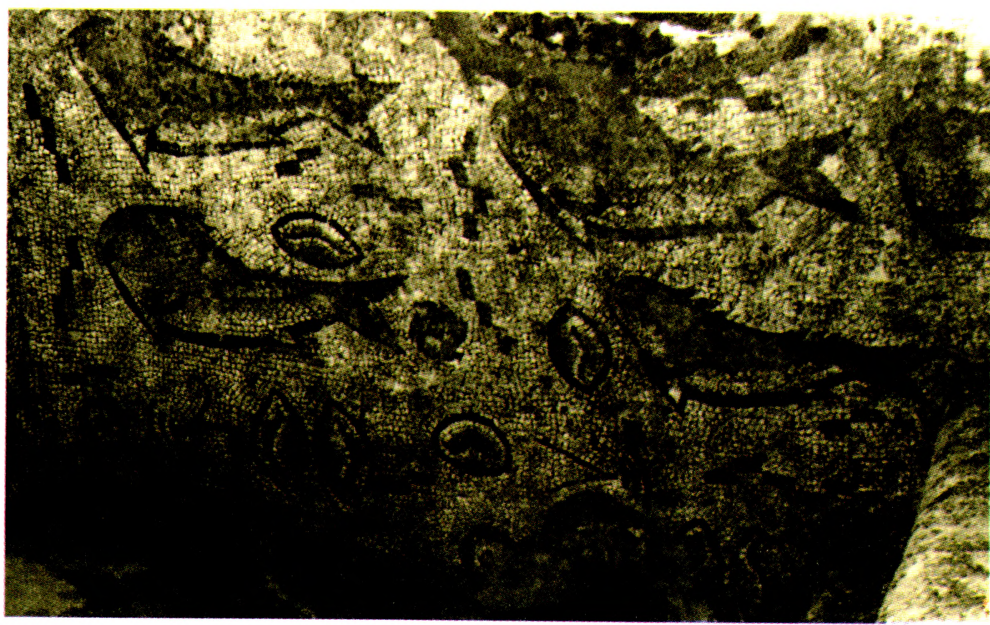

Fig. 5 - Mosaico das termas da villa de Milreu (Estói, Faro) com temática marinha.

\footnotetext{
${ }^{(18)}$ J. Lancha, La mosaïque d'Ocean découverte à Faro, "Conimbriga", XXIV, 1985, p.160-170.

(19) V. Mantas, A cidade luso-romana de Ossonoba, "Actas del I Coloquio de Historia Antigua de Andalucía”, I, 1993, p.521-523.
} 
Ainda algumas breves reflexões acerca da rara presença de navios na iconografia dos mosaicos romanos da Lusitânia. O interesse por temas do quotidiano tratados de forma realista, que marcou profundamente determinados contextos da arte romana, parece não ter tido grande influência no âmbito do grupo que podia encomendar trabalhos aos mosaístas, mais interessado em temas literários, mitológicos ou puramente ornamentais. Esta circunstância não é invulgar na sociedade romana, embora pareça contraditória, pois, por exemplo, acontece o mesmo em relação à construção de vias, cujos aspectos técnicos são quase totalmente desconhecidos na literatura latina, passe a importância real que os caminhos terrestres tinham no mundo romano, inclusive do ponto de vista da simbologia política ${ }^{(20)}$. Sendo lógico que construções relacionadas com determinadas actividades reflictam, na sua decoração, essas actividades, caso, por exemplo, das stationes do Forum das Corporações, em Óstia, ou da schola de uma das facções do circo, em Cartago ${ }^{(21)}$, também é normal que os mosaicos de espaços de habitação privados se relacionem, antes de mais, com os interesses culturais decorrentes da formação dos proprietários ou com as modas divulgadas a partir de determinados centros ou por artistas itinerantes. Finalmente, sem esquecer o problema arqueológico subjacente, devemos considerar que o comércio marítimo da Lusitânia dependeu longamente de uma estrutura que lhe era alheia no essencial, o que pode ter contribuído para limitar a proliferação da iconografia naval.

Tudo o que dissemos atrás serve para valorizar os raros testemunhos iconográficos de navios que chegaram até nós em mosaicos luso-romanos. Antes de nos ocuparmos da questão do valor destas representações do ponto de vista da arqueologia naval, devemos recordar outros testemunhos lusitanos

\footnotetext{
(20) Vias e pontes foram utilizadas exaustivamente para projectar a imagem de força e de unidade própria da ideologia imperial: T. Donaldson, Ancient Architecture on Greek and Roman Coins and Medals, Chicago, 1966, p.235-249, pl. 60-65; F. Kleine, The trophy on the bridge and the Roman triumph over nature, "L’Antiquité Classique", 60, 1991, p.182-192.

(21) R. Meiggs, Roman Ostia, Oxford, 1960, p.329-331, 446-454, pl. XXIII-XXV ; G. Ch.-Picard, La Carthage de saint Augustin, Paris, 1965, p.91-95.
} 
também relacionados com navios e igualmente raros, como são as moedas. Referimo-nos, naturalmente, a emissões monetárias de cidades lusitanas, as únicas que poderão facultar algumas informações sobre a tecnologia naval existente na Lusitânia ou aqui conhecida, pois as emissões normais, onde a presença de navios ou partes de navios é recorrente, quer no período republicano, quer na época imperial, não reflectem as realidades regionais. Alguns dos navios foram representados de forma tão fruste que não é possível extrair qualquer indicação sobre a tipologia dos mesmos. Assim sucede, por exemplo, com a embarcação figurada numa emissão de sextantes de Balsa (Luz de Tavira), um navio de formas arredondadas, baixo sobre a água, aparentemente com a popa à direita ${ }^{(22)}$. Pode tratar-se da representação estilizada de uma embarcação cerimonial, uma vez que a árvore que transporta a meio-navio a relaciona com mitos de origem oriental, de larga difusão no mundo greco-romano e claramente representados nesta cidade luso-romana do litoral algarvio ${ }^{(23)}$.

Não menos interessantes, e em certos casos bastante mais precisas no tocante à iconografia dos navios, são as moedas cunhadas em Ossonoba (Faro), nas quais podemos distinguir diferentes modelos ${ }^{(24)}$. É particularmente interessante um dos navios representados nestas moedas (Fig.6), cujo desenho foi retomado de forma menos cuidada numa das emissões de menor valor aquisitivo. Com a popa à direita, rematada por um elegante aplustrum, vela redonda enfunada e cuidadosa representação do cordame, nomeadamente dos rizes e da mesa de guarnição onde estes se fixam, transmite uma invulgar impressão de elegância, própria de uma embarcação marinheira. Está ainda representado o leme lateral e, cremos, o pontalete de suporte do maștro, destinado a apoiá-lo quando abatido, tal como aparece em conheci-

(22) A. M. Faria, Moedas de época romana cunbadas no actual território algarvio, "Noventa Séculos Entre a Serra e o Mar", Lisboa, 1997, p.362-363.

${ }^{(23)}$ V. Mantas, $A$ cidade de Balsa, "Tavira. Território e Poder", Lisboa, 2003, p.86-87.

(24) Faria, p.368-369. 


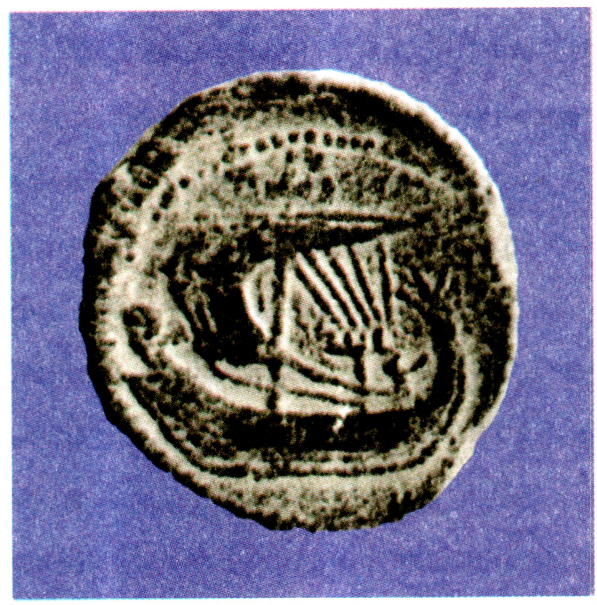

Fig. 6 - Anverso de um asse de Ossonoba (Faro) figurando um navio mercante.

dos mosaicos da região tunisina de Sousse ${ }^{(25)}$. O desenho a vante é mais complicado, mostrando uma roda de proa direita, a que se sobrepõe um elemento decorativo de difícil interpretação, que pode corresponder a um emblema ou à tutela do navio. No topo do mastro parece estar representado o cesto da gávea (charchesium), neste caso uma simples plataforma rectangular. Alongámo-nos na descrição desta embarcação por se afastar das representações muito sintéticas de outros testemunhos da numária lusitana e também por possuir algumas características semelhantes às corbitae presentes no mosaico de Vega Baja de Toledo, sobretudo com uma delas (Fig.7), se exceptuarmos o elemento que sobrepuja a proa do navio ossonobense, que recorda a estranha colocação do beque numa actuaria representada num mosaico africano de Sousse ${ }^{(26)}$, nitidamente desligado da roda de proa.

Uma outra moeda de Ossonoba, rara, tanto quanto sabemos ${ }^{(27)}$, mostra um navio de desenho bastante imperfeito, de formas algo pesadas, aparentando fraco quociente de finura (Fig.8). A roda de proa, à direita, parece terminar

(25) L. Casson, Ships and Seamanship in the Ancient World, Baltimore, 1995, p.329, fig.191 (=Casson, Ships); Pomey, p.75, 159.

(26) Pomey, p.84.

(27) O. G. Farrés, La moneda bispánica en la Edad Antigua, Madrid, 1966, p.316-320; J. Alarcão, Portugal romano, 1987, p.85. Esta moeda pertencia ao medalheiro do Palácio Nacional da Ajuda. 


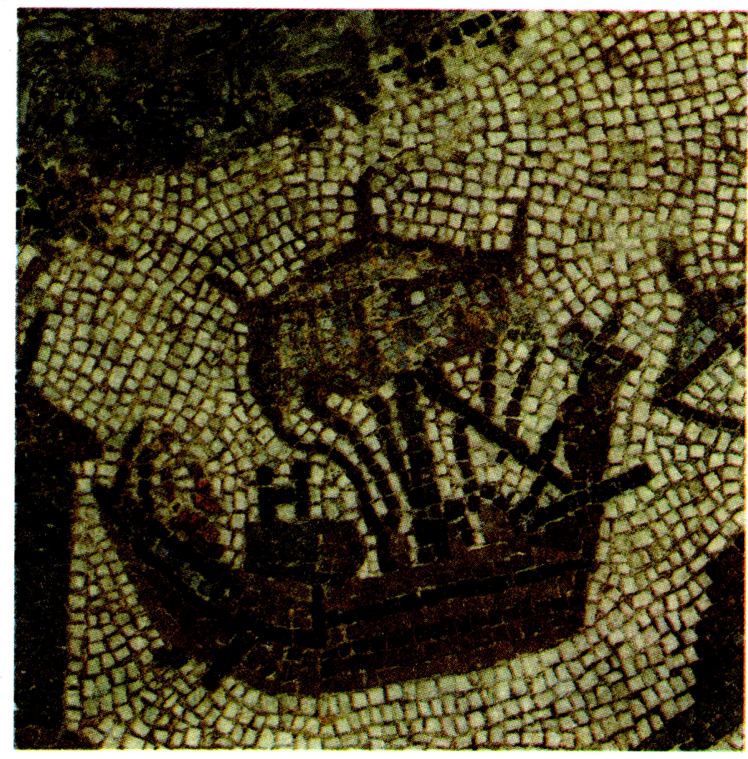

Fig. 7 - Navio mercante do mosaico de Vega Baja (Toledo).

num longo beque, bastante invulgar. Pertence, como os restantes, à classe das naves onerariae, designação geral para os navios de carga romanos, sem que possamos precisar exactamente que tipo representa, embora, como veremos

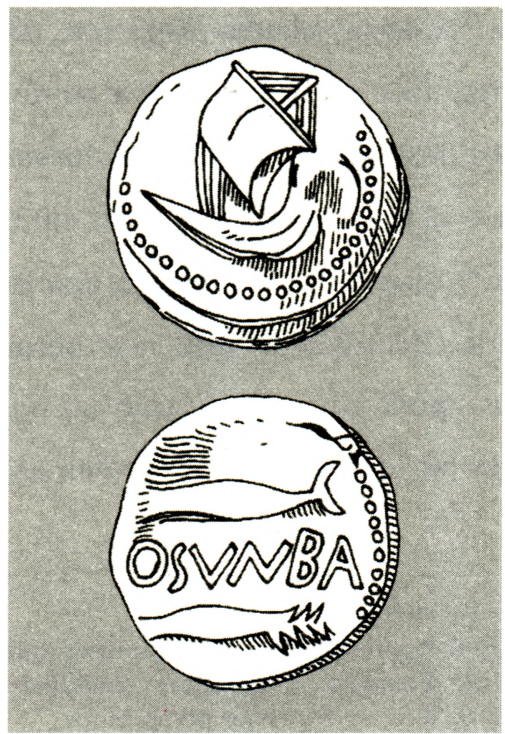

Fig. 8 - Moeda de Ossonoba com representação de navio mercante de tipo local (?). 
adiante, talvez seja possível relacioná-lo com uma embarcação em uso na área ibero-africana do Império Romano. É evidente que a qualidade das representações, fracas e por vezes difíceis de analisar, como neste último caso, aconselha bastante prudência quando se procura identificar a tipologia dos navios em questão. Julgamos, porém, que as moedas de Ossonoba não se limitaram a representar embarcações irreais ou simplesmente copiadas de fontes alheias à região, pois incluem alguns elementos pouco comuns. As moedas algarvias foram cunhadas no século I a.C., segundo tudo leva a $\operatorname{crer}^{(28)}$, mas tal facto não constitui problema, pois a tecnologia naval permaneceu longamente inalterada em muitos aspectos básicos, pelo que a iconografia dos navios não acusa grandes diferenças, sobretudo em representações sumárias, excepto quando se pretende voluntariamente evidenciar o que, por alguma razão, não é habitual.

Todo o material que referimos foi já publicado, situação que igualmente se verifica em relação aos três mosaicos que constituem o motivo desta comunicação. Apesar disso, como a análise dos navios nunca foi efectuada de forma desenvolvida, com uma única excepção no que se refere aos mosai$\cos ^{(29)}$, pareceu-nos útil destacar alguns aspectos relevantes patentes na iconografia dos navios figurados nas moedas, por se revelarem úteis na interpretação das embarcações ilustradas nos mosaicos lusitanos. Esperemos que a arqueologia subaquática e a exploração das zonas húmidas do litoral português permitam recuperar restos de navios e não apenas traços da sua carga ou do seu equipamento, circunstância que nos permitiria, eventualmente, acrescentar alguma coisa significativa em relação ao conhecimento dos mesmos, por enquanto ainda tão dependente de fontes escritas e iconográficas, muito limitadas.

\footnotetext{
(28) Faria, p.369. Aproveitamos a oportunidade para esclarecer que não consideramos estas moedas emissões dos filhos de Pompeio, o que lhes conferiria outra tipologia, mas sim cunhagens locais num contexto político favorável aos pompeianos.

(29) F. Alves, Por mosaicos nunca dantes navegados, "Conimbriga", XXXII-XXXIII, 1993-1994, p.247-261.
} 
Dos três mosaicos considerados vamos analisar em primeiro lugar, na parte que interessa, o mosaico com um friso nilótico, achado em Mérida em 1834 nas ruínas de uma casa na Calle Sagasta ${ }^{(30)}$, perto do Forum, e durante muito tempo conservado na Alcazaba, onde o vimos em 1981, encontrando-se na actualidade no Museo Nacional de Arte Romano. Trata-se de um mosaico em que predomina o preto e o branco, de grandes dimensões, atribuído ao período situado entre finais do século II e inícios do século IV, segundo os diferentes investigadores que o estudaram, com preferência para uma datação baixa no horizonte cronológico proposto ${ }^{(31)}$. O mosaico está assinado por dois artistas, Seleucus e Anthus, cujos nomes apareciam numa elegante cartela precedidos das siglas CAEF, decerto correspondentes a C(olonia) A(ugusta) $\mathrm{E}$ (merita) $\mathrm{F}$ (ecerunt). O friso nilótico, com os seus elementos habituais, embarcações, crocodilos, pigmeus, aves e palmeiras, é secundário na economia da obra, funcionando como cercadura da composição central.

Neste friso, pertencente a um tipo de que existem na Hispânia outros exemplos ${ }^{(32)}$, estão representadas quatro embarcações fluviais, uma das quais não figura no desenho do mosaico da autoria de Mariano de Albo (Fig.9). Destas, duas exibem de forma fantasista, pirogas, uma delas típica do Nilo, aparentemente construída com fibras vegetais, tal como ocorre no célebre mosaico de Palestrina, ainda que no mosaico emeritense surja dotada da vela característica dos navios romanos, tudo pouco credível. No mesmo registo encontra-se uma terceira embarcação, de casco simétrico, dotada de um velame idêntico ao que referimos anteriormente, embora mais completo, pois representa as sipara triangulares que encimavam a vela principal. Esta embarcação mostra um pormenor muito interessante e que permite, para além da fantasia e da simplicidade da representação, classificá-la como de tipo

\footnotetext{
(30) A. B. Freijeiro, Corpus de Mosaicos de España, I, Mosaicos de Mérida, Madrid, 1978, p. 30-32, lâm.12-19.

${ }^{(31)}$ Freijeiro, p.32; Lancha, Mosaïque, p.218.

${ }^{(32)}$ Blázquez, p.34-35; Lancha, Mosaïque, p.213-218, 368-369.
} 
fluvial, que é a existência de lemes à popa e à proa. Esta particularidade técnica relaciona-se com a necessidade de efectuar manobras em espaços de alguma forma limitados, nomeadamente quando se tratava da travessia de rios ou de canais, existindo testemunhos da sua utilização em diversos locais do mundo romano(33).

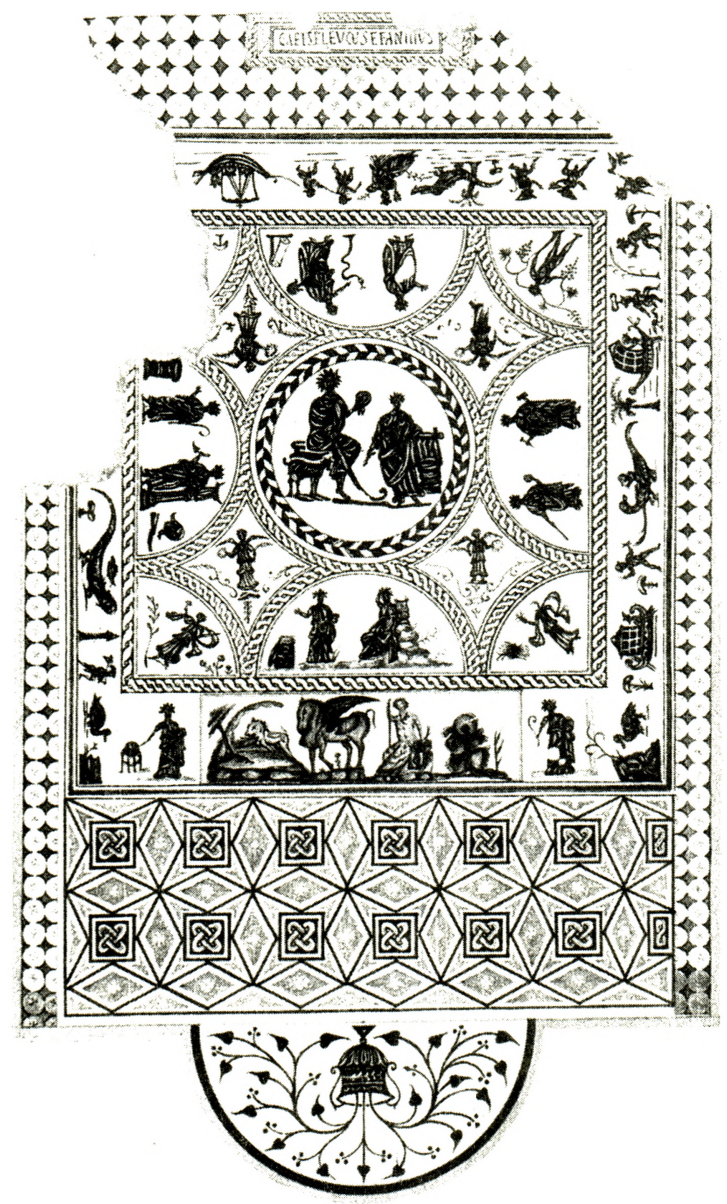

Fig. 9 - Desenho de M. de Albo (século XIX) representando o mosaico da Calle Sagasta, Mérida (Gentileza do Museo Nacional de Arte Romano).

(33) Por exemplo, na Germânia e na Gália: Leclercq, col.986-987. 
Os três casos anteriores combinam, da forma habitual neste tipo de composições, muita fantasia com alguma realidade. No mosaico da Calle Sagasta as embarcações figuradas sugerem-nos a ideia, talvez audaciosa, de que os artistas pretenderam ilustrar três níveis de construção e de utilização de embarcações fluviais, ou seja, as pequenas embarcações tradicionais, as embarcações de exclusiva utilização fluvial, especializadas, tipo ferry-boat, e os navios fluviais com maior capacidade e capazes de navegação marítima de cabotagem, se necessário. Uma vez que o mosaico foi composto em Mérida, cidade debruçada sobre um rio importante, grande eixo de penetração do Golfo de Cádis para o interior da Península Ibérica e navegável por troços até à capital lusitana, o que não pode deixar de ter sido aproveitado na época romana ${ }^{34}$, cremos possível que as três primeiras embarcações referidas tenham respeitado o modelo nilótico, salvaguardando assim o exotismo que se pretendia transmitir, ao passo que a quarta embarcação, que analisamos de seguida, possa reflectir alguma coisa da realidade regional lusitana, tanto mais que o tratamento do navio e a cena representada são muito mais realistas.

O mosaico mostra uma manobra típica da navegação fluvial ou de canal, com um grupo de sirgadores (belciarii) alando a embarcação da margem (Fig.10). Para facilitar a deslocação do navio o leme lateral está levantado, o que corresponde a uma prática normal em casos de reboque ou de manobra no interior de portos. A fase preparatória da operação de levantamento dos lemes, bastante complicada em embarcações de porte significativo, encontrase representada no conhecido relevo da colecção Torlonia que mostra um navio a aportar a Óstia(35). A embarcação do mosaico emeritense transporta um carregamento de ânforas globulares, de tipologia obscura, antes ou após um transbordo, como sugere a operação de reboque. Conta com um mastro único, situado ligeiramente a vante, o que é vulgar em navios fluviais, armando

\footnotetext{
(34) L. A. Curchin, Communications fluviales en Lusitanie, "Las Comunicaciones en Lusitania Romana", Madrid, 2004, p.455-463.

(35) Casson, Ships, p.224-228, fig.144, 146.
} 


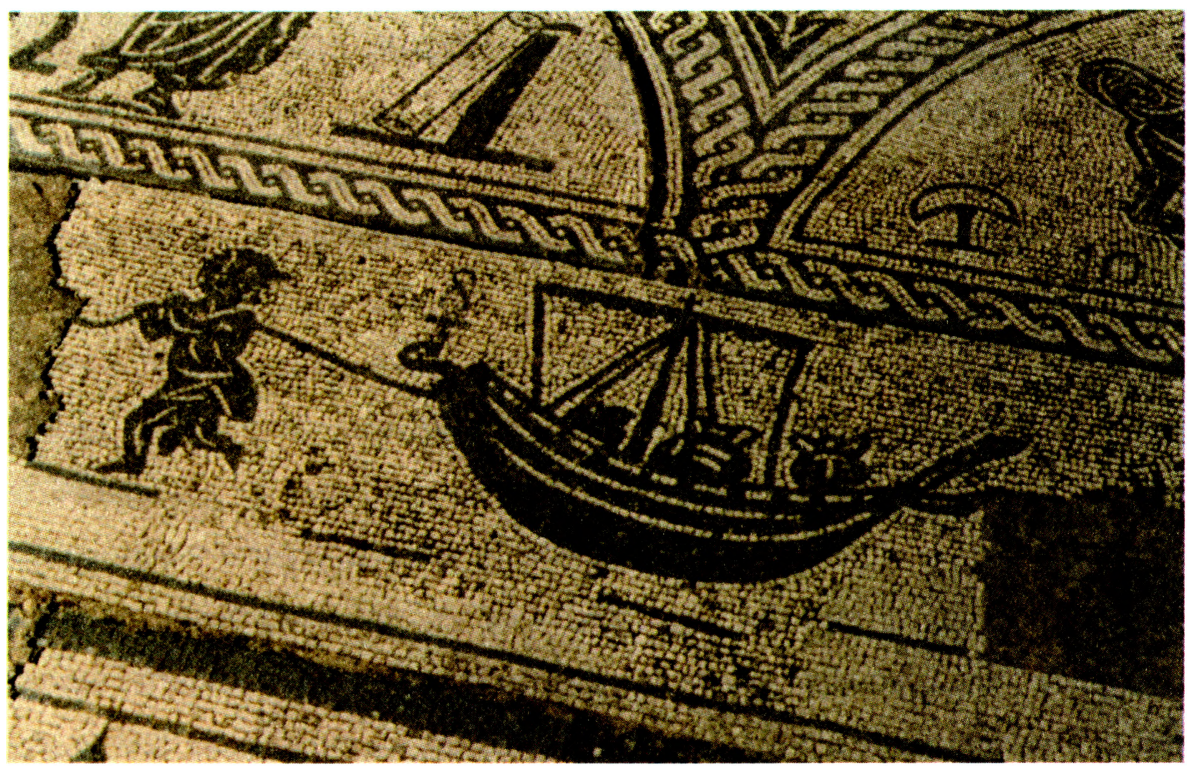

Fig. 10 - Navio fluvial do friso nilótico do mosaico da Calle Sagasta, Mérida.

com uma vela redonda, cuidadosamente ferrada. O cordame, embora sumariamente representado, mostra correctamente os braços e os brandais $\mathrm{O}$ casco tem formas arredondadas e conta com duas cintas bem desenhadas, o que permite considerar tratar-se de uma embarcação com alguma dimensão e capacidade de carga. A rabada do navio prolonga-se de forma um tanto exagerada, mas que não é invulgar na iconografia dos navios antigos, enquanto que a roda de proa termina abruptamente e é decorada com um elemento em forma de gancho, que recorda vagamente o que ocorre numa das moedas de Ossónoba.

Embora não seja fácil a classificação tipológica deste navio, muito diferente do que se identifica na maioria dos mosaicos de temática marítima e que se aproxima muito, na técnica do desenho, dos navios representados nos mosaicos de Óstia, circunstância que favorece a proposta de datação alta, julgamos ser possível integrá-lo no grupo das caudicariae, navios fluviais de razoável dimensão, bem conhecidos pela sua actividade no Tibre, mas que 
existiam igualmente noutras regiões do Império, incluindo, com toda a probabilidade, a Lusitânia ${ }^{(36)}$. O desenho do casco não se opõe a tal hipótese, o mesmo sucedendo com a implantação do mastro, pelo que os artistas, que Janine Lancha, contrariamente a Blanco Freijeiro, considera de origem italiana ${ }^{(37)}$, poderão ter representado uma embarcação flúvio-marítima de um tipo regional, aparentada com as caudicariae italianas. A importância do tráfico marítimo no Guadiana até Mértola, inquestionável, e a facilidade de utilizar o rio a montante do Pulo do Lobo, depois de um breve trajecto terrestre, obrigam a considerar seriamente a hipótese que aqui desenvolvemos.

O segundo mosaico que vamos comentar por nele figurar um navio é o conhecido mosaico da villa de Santa Vitória do Ameixial, nos arredores de Estremoz, com a representação do famoso e muito popular episódio de Ulisses ouvindo o canto das Sereias, cena que ocupa um painel de uma composição bastante mais vasta e sem unidade aparente. Este mosaico tem conhecido uma história atribulada desde o seu levantamento das ruínas da villa, pertencendo ao acervo do Museu Nacional de Arqueologia. Tal como acontece no mosaico de Mérida que referimos atrás, o mosaico do Ameixial indica também o nome do artista, perdido, precedido na primeira linha pelas siglas $\mathrm{KAF}$, segundo Lancha, mas que interpretamos antes como KAE, que se deve desenvolver como K(olonia) A(ugusta) $\mathrm{E}$ (merita). Esta versão pode significar que os artistas tinham a sua oficina em Mérida ou que a zona de Estremoz pertencia ao território colonial emeritense, como outros testemunhos sugerem fortemente ${ }^{(38)}$. Seja como for, a relação desta zona da

\footnotetext{
(36) L. Casson, Harbor and river boats of Ancient Rome, "The Journal of Roman Studies", LV, 1965, p.36-39. A existência de numerosos portos flúvio-marítimos no território lusitano, aliada a uma importante navegação de cabotagem entre eles, sugere fortemente a possibilidade de aqui terem existido embarcações tipo caudicaria, talvez indirectamente referidas numa inscrição de Santiago do Cacém, perdida e de difícil interpretação (CIL II 25=IRCP 150).

${ }^{(37)}$ Lancha, Mosaïque, p.218.

${ }^{(38)}$ R. Plana-Mallart, Ebora et son territoire, "Cité et Territoire", Paris, 1995, p.235. Nos arredores de Estremoz são evidentes traços de centuriação que se dirigem em direcção à fronteira luso-espanhola, ocupando uma zona de abundantíssimos vestígios romanos.
} 
Alto Alentejo com a capital lusitana resulta muito nítida através desta circunstância.

Não nos ocuparemos, naturalmente, com a análise global deste mosaico, pertencente às termas da villa, sobre o qual a bibliografia é abundante ${ }^{(39)}$, focando a nossa atenção na cena da navegação de Ulisses junto ao rochedo das Sereias e, em especial, no navio navio nela representado. Não são abundantes na Lusitânia, apesar da tradição antiga aqui situar algumas das andanças do herói, testemunhos artísticos directamente relacionados com os relatos homéricos ${ }^{(40)}$. Uma das cenas mais documentadas da Odisseia é, exactamente a do célebre episódio em que Ulisses enfrenta as Sereias (Fig.11). Como é sabido, as Sereias atraíam com o seu belo canto os marinheiros, causando a sua perdição, destino a que Ulisses escapou, avisado por Circe, tapando com cera os ouvidos dos companheiros e fazendo-se atar ao mastro ${ }^{(41)}$. A cena no mosaico de Santa Vitória do Ameixial é perfeitamente clássica, contando com todos os elementos que lhe são próprios.

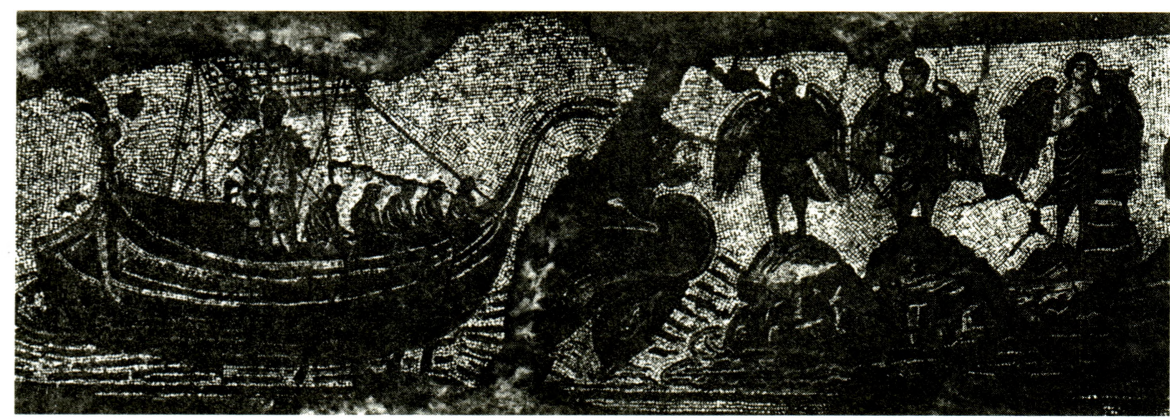

Fig. 11 - Painel do mosaico de Santa Vitória do Ameixial representando a navegação de Ulisses junto à ilha das Sereias.

\footnotetext{
(39) Lancha, Mosaïque, p.256. Neste trabalho utilizámos fotografias anteriores à deplorável intervenção que o mosaico sofreu

(40) V. Mantas, Penélope e Ulisses na Lusitânia, "Penélope e Ulisses", Coimbra, 2003, p.145-166 (=Mantas, Penélope).

(41) Homero, Od., XII, 39-54, 154-200; B. Candida, Tradizione figurativa nel mito di Ulisse e le sirene, "Studi Classici e Orientali", XIX-XX, 1970-1971, p.212-251.
} 
Parece não haver dúvidas quanto à influência norte-africana neste mosaico, cuja composição recorda francamente as que ocorrem em mosaicos com o mesmo tema achados em Thugga, na Tunísia, e em Cherchel, na Argélia. Neles encontramos o navio à esquerda, Ulisses atado ao mastro, sem olhar as Sereias, e estas, figuras hibrídas, passariformes, colocadas à direita da composição, numa posição dominante ${ }^{(42)}$. Dois reparos, todavia, em relação ao mosaico de Thugga. Neste, existe uma clara opção pela frontalidade na representação das figuras, bastante vulgar na arte norte-africana e oriental a partir de finais do século $\mathrm{II}^{(43)}$, o que não se verifica na cena do mosaico lusitano, que Janine Lancha data do período entre 268 e 330. Por outro lado, no mosaico tunisino o navio afasta-se do rochedo das Sereias, navegando num mar onde não faltam outros motivos. Na verdade, comparando as duas cenas, a de Santa Vitória do Ameixial resulta mais realista, se nos é lícito falar de realismo neste tipo de iconografia. Esta questão é, porém, importante, como veremos.

A inclusão desta cena literária no mosaico lusitano não pode ser interpretada como indício de qualquer outra coisa que ultrapasse o gosto do proprietário da villa por assuntos decorrentes de uma educação que não podia ignorar a temática homérica. A repartição conhecida da mesma cena, em mosaicos, não deixa de ser indicativa do que se passava na Península Ibérica, nomeadamente na Lusitânia, no período ao qual se atribui o mosaico alentejano. Com efeito, são muito numerosos os testemunhos arqueológicos de um incremento assinalável das relações com o Norte de África, que ocupa uma posição central nas rotas marítimas e no comércio lusitano, suplantando as ligações que anteriormente privilegiavam a Bética ${ }^{(44)}$, pelo que a presença de temas populares em África é perfeitamente normal. Dos mosaicos em que a cena da navegação de Ulisses junto à ilha das Sereias se encontra

\footnotetext{
${ }^{(42)}$ Lancha, Mosaïque, p.71, 82, pl. XXII, XXIX.

${ }^{(43)}$ M. Wheeler, Roman Art and Architecture, Londres, 1964, p.167-169,190-193.

(44) Mantas, Navegação, p.231-238.
} 
representada, um achou-se em Israel, um em Portugal, três em Itália e seis no Norte de África. Esta preponderância do tema em África torna-se ainda mais significativa uma vez que se trata de mosaicos atribuídos aos séculos III e IV, período a que pertence o mosaico de Santa Vitória do Ameixial, enquanto que os mosaicos italianos datam dos séculos I e II.

Como a História Antiga depende do cruzamento de informações das mais diversas fontes, escritas e arqueológicas, ocorre-nos o problema da ausência quase total na onomástica peninsular de mitónimos relacionados com os heróis homéricos, em particular das figuras centrais da Odisseia. Julgamos que esta circunstância, difícil de explicar considerando a difusão, ainda que limitada, da temática homérica, inclusive em objectos de uso corrente, como as lucernas ${ }^{(45)}$, poderá resultar quer de questões de mentalidade, quer da coincidência do período em que a influência africana aumenta com o fenómeno do decréscimo acelerado da prática epigráfica, sobretudo a nível privado. Na verdade temos poucos monumentos para que possamos, por ora, desenvolver este tipo de análises, apresentadas como simples hipóteses de trabalho.

A investigadora francesa Janine Lancha propõe, cremos que com toda a razão, que o artista que concebeu o mosaico utilizou dois cartões distintos, um para as Sereias, muito clássicas no seu aspecto e postura, e outro para o navio ${ }^{(46)}$. Esta circunstância parece-nos relevante quanto à interpretação do tipo da embarcação representada (Fig.12), que Francisco Alves considera uma completa fantasia $^{(47)}$, opinião com que não concordamos. Antes de mais devemos precisar o sentido da marcha do navio, ou seja, onde está a proa, questão que tem dividido os diferentes autores que se têm ocupado da questão. Trata-se, na verdade, de uma falsa questão. Jorge de Alarcão não

\footnotetext{
(45) Mantas, Penélope, p.155-159.

(46) Lancha, Mosaïque, p.257.

(47) Alves, p.259-260. O autor admite, todavia, a hipótese de se tratar de uma representação influenciada por algum modelo regional.
} 


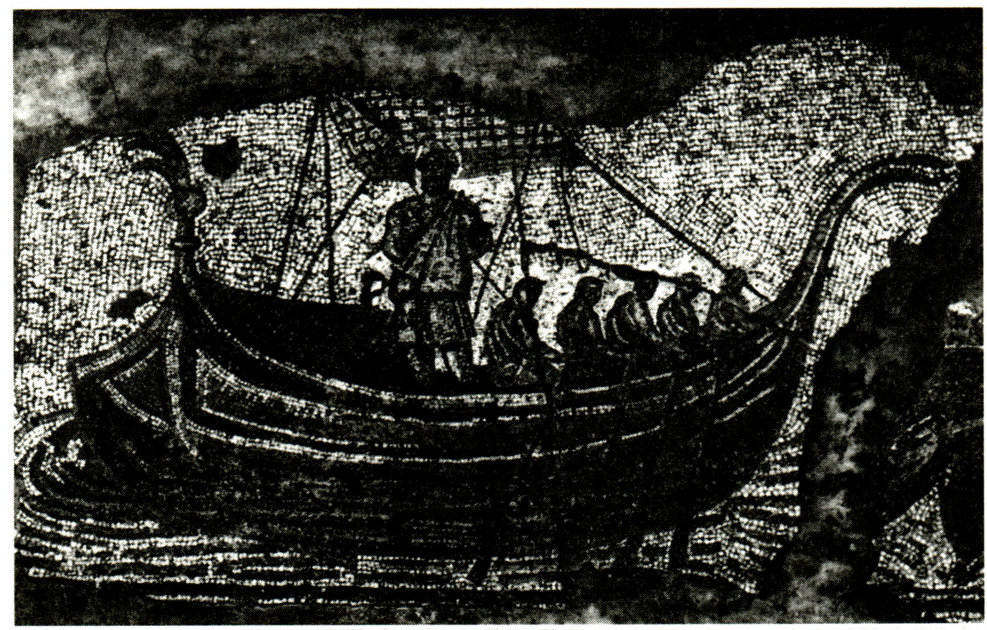

Fig. 12 - O navio de Ulisses no mosaico de Santa Vitória do Ameixial (Estremoz).

hesitou em considerar a proa à direita, correctamente, o que não aconteceu com as análises de Torres Carro e de Janine Lancha, que consideram a proa à esquerda da figura ${ }^{(48)}$. Esta errada interpretação deve-se, em grande parte, à posição anormal dos remadores, ao contrário da que seria de esperar, o que, sendo pouco satisfatório, não representa um problema insolúvel neste tipo de iconografia. No navio de Thugga, por exemplo, os companheiros de Ulisses não só ocupam uma posição que os impediria de remar como estão armados de escudo. Assim, não hesitamos em considerar que a proa do navio se situa à direita da figura, apontando à ilha das Sereias.

Existem outros elementos para apoiar a nossa interpretação. A rabada do navio, à esquerda, termina não com um facho de sinalização, como já foi defendido ${ }^{(49)}$, mas sim pelo característico aphlaston ou aplustrum, e é perfeitamente visível, não sendo susceptível de outra interpretação, o abrigo, vulgar à

\footnotetext{
(48) Alarcão, Portugal, p.203; M. T. Carro, La escena de Ulises y las Sirenas del mosaico de Santa Vitoria (Portugal), "Boletin del Seminario de Estudios de Arte y Arqueología", XLIV, 1978, p.95-97; Lancha, Mosaïque, p.256-257.

(49) E. B. Garcia, As torres e os fachos na Lagoa da Pederneira. Vestígios de navegações antigas na Lagoa da Pederneira (Nazaré), "Arquivo de Beja", 25-27, 1968-1970, p.73, fig. 9.
} 
popa dos navios romanos pelo menos a partir dos finais da República ${ }^{(50)}$. A análise da vela da embarcação, desenhada com algum pormenor, mostra o 314 típico aspecto quadriculado do pano de muitas embarcações romanas. Bastaria um pormenor desta vela para resolver imediatamente a velha questão da proa e da popa do navio de Ulisses. Com efeito, a vela mostra uma dobra no canto inferior esquerdo, de forma que nunca poderia estar nesta posição se a proa se situasse à esquerda, pois o punho da vela recolhido deve estar sempre do lado da popa, para onde correm as escotas. Na figura do navio falta a representação do leme, o que não é muito habitual. Talvez a presença do abrigo à popa tenha dificultado a inclusão desse elemento, que se pode supor existir a bombordo. O mosaico que se encontra à direita, junto à proa, e que não rema, pode estar a sondar o fundo, uma vez que se navegava junto a uma ilha desconhecida. A figura mostra ainda a cinta da embarcação, que parece ser bastante robusta. Finalmente, convém atender a que o navio é representado segundo diferentes perspectivas, de lado e a três quartos.

A reconstituição do perfil do navio, mostra tratar-se, mais uma vez, de uma embarcação simétrica, terminando a roda de proa por um longo beque, que não pode deixar de nos sugerir o que parece estar presente num dos navios figurados nas moedas de Ossónoba que referimos atrás. Esta circunstância, aliada ao facto do navio ter sido desenhado a partir de um cartão diferente do que foi utilizado para as Sereias, como parece evidente, permite considerar a hipótese de se tratar de um tipo de embarcação realmente existente, conhecida na Lusitânia. Podemos, desde já, classificá-la como actuaria, um navio comercial movido à vela e a remos, embora muitas das embarcações deste tipo possuam uma espécie de esporão, semelhando navios de guerra ${ }^{(51)}$, o que não acontece neste caso. Uma vez que os remos se apoiam na amurada, sem que se lhes representem os toletes, é claro existir apenas uma ordem de remadores, como é normal nas actuariae, independentemente das

\footnotetext{
(50) Casson, Ships, p.179-180.

${ }^{(51)}$ Casson, Ships, p.157-160, fig.137, 140.
} 
suas dimensões. Neste caso, a embarcação representada, talvez desprovida de coberta, seria relativamente pequena.

De tudo o que se pode verificar na figura, ou deduzir, cremos possível admitir, descontando a falta de precisão do artista que compôs o mosaico, ter sido utilizado um cartão representando um navio de pequeno porte, provavelmente usado na navegação de cabotagem. Não nos parece arriscado identificá-lo com as barcae, embarcações conhecidas no Sul da Lusitânia, como demonstra a inscrição de Balsa que refere um barcarum certamine (CIL II 13=IRCP 73). Esta inscrição (Fig.13), consagrada a Fortuna Augusta pelo séxviro Annius Primitivus e datada do século III, contém a primeira referência conhecida ao vocábulo barca, o qual ganhará uma utilização generalizada a partir da Antiguidade Tardia ${ }^{(52)}$. A cronologia desta epígrafe e o facto de haver notícia da existência de uma força auxiliar naval estacionada na Mauritânia, também no século III, cujos tripulantes são designados como barcarii ${ }^{(53)}$, e ainda uma referência na Notitia Dignitatum, uma espécie de ordem de batalha tardia das forças militares romanas, a um numerus barcariorum estacionado na Britânia ${ }^{(54)}$, concorrem para que estejamos perante a representação de um navio de tipo regional, idêntico aos que eram eventualmente

13 Reperta c. a. 1750 ad mare, postea in eccl. 'de la Luz' Acuña. 'No plinto do pulpito da igreja de N. S. da Luz, uma legoa de Tavira' da Veiga.

Acuña 3, 3. Descripsit mihique dedit Estaco da Teiga (ab eodem habuit Levy, 12, 36). Fdidi act. Berol. a. 1861 p. 752.
FORTVNAE - AVG

SACR

ANNIVS - PRIMITIVVS

O B HONOREM

IIIII $\cdot$ VIR $\cdot$ SVI

EDITO - BARCARVM

CERT AMINE - ET

PVGILVM-SPORTVLIS

E TI A M CIVIBVS

DATIS

D. S P P D D D

Fig. 13 - Inscrição de Balsa (Luz de Tavira), referindo um barcarum certamine (CIL II 13).

\footnotetext{
(52) Rodríguez-Pantoja, p.143. Emil Hübner considerava o vocábulo de origem fenícia: Monumentos de Balsa (perto de Tavira), "Revista Archeologica e Histórica", I, 1887, p.34.

${ }^{(53)}$ C. G. Starr, The Roman Imperial Navy, Chicago, 1993, p.120,123.

${ }^{(54)}$ Not. Dig. Occ., 40, 22.
} 
utilizados como embarcações auxiliares em situações de emergência ou em operações militares de limitada envergadura.

316 O terceiro mosaico que na Lusitânia conservou uma figura de navio foi achado nas ruínas da imponente villa de Milreu, situada junto a Estói, perto de Faro. A análise deste mosaico é difícil, uma vez que se limita a um pequeno fragmento, cuja origem exacta é difícil de precisar. Com efeito, se o local onde foi achado não constitui problema, é mais complicado estabelecer com precisão em que área ou construção das ruínas da villa foi encontrado o mosaico a que pertenceu o fragmento com a representação truncada de uma embarcação de que nos ocupamos recentemente prejudicado por uma desnecessária operação de restauro. Sabemos que foi recolhido por Estácio da Veiga durante as escavações a que procedeu no século XIX em Milreu ${ }^{55 ;}$; arqueólogo que o ofereceu à Rainha D. Amélia, cujo interesse pela investigação arqueológica merece ser recordado e louvado, encontrando-se actualmente no Museu Nacional de Arqueologia(56). O fragmento assim preservado pertenceu a um mosaico polícromo, como outros que se conhecem em Milreu, conservando restos da moldura que circundava o tema ou o painel a que pertencia o navio (Fig.14).

O primeiro problema a enfrentar é, portanto, o da localização do mosaico nas ruínas. Se tivermos em consideração o desenho da moldura podemos admitir que Estácio da Veiga recuperou o fragmento, que considerou particularmente interessante por se tratar de um motivo invulgar nos mosaicos romanos do território português, nas ruínas do templo da villa, concretamente no mosaico parietal do pódio. O facto da embarcação estar representada muito perto do limite do mosaico não deixa de sugerir que se encontrava integrada numa composição onde o espaço disponível não seria muito, ao

\footnotetext{
(55) Sobre as escavações deste notável pioneiro da arqueologia portuguesa em Milreu: M. L. Afonso dos Santos, Arqueologia romana do Algarve, II, Lisboa, 1972, p.179-236.

(56) J.S. Machado, Documentos de Estácio da Veiga para o estudo da arqueología do Algarve, "Actas das I Jornadas Arqueológica", I, Lisboa, 1970, p.360.
} 


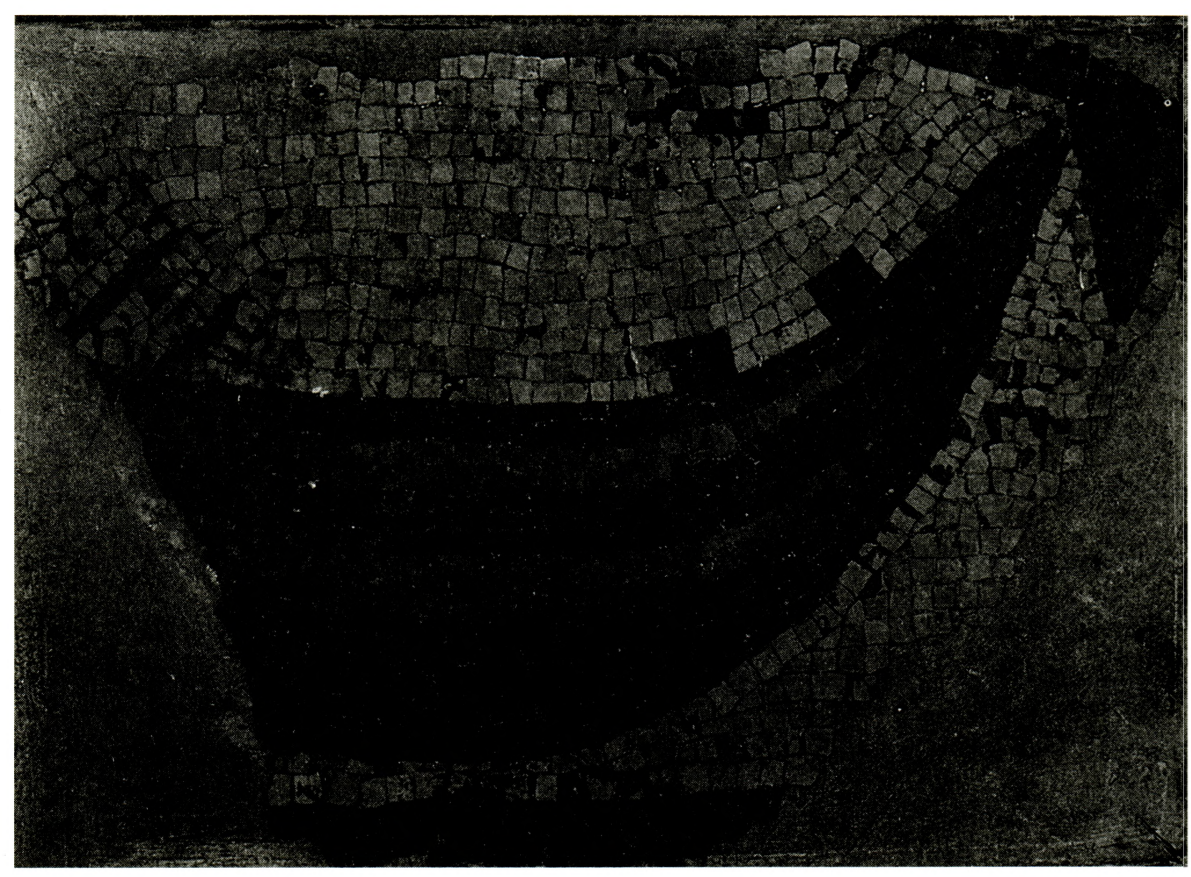

Fig. 14 - Navio de um mosaico da villa romana de Milreu ( Estói, Faro).

contrário do que normalmente acontece nos mosaicos de pavimento, onde este tipo de figuras aparece menos coagido por outros elementos. Que figurasse uma embarcação no mosaico de temática marítima do pódio parece-nos normal, como elemento decorativo perfeitamente adequado ao tema e ao ambiente. Todavia, embora de momento não o possamos provar, devemos referir que nos recordamos de ter visto, na primeira visita que fizemos ao Museu Nacional de Arqueologia, há cerca de meio século, num dos expositores com materiais de Milreu, uma fotografia de um pavimento de mosaico no qual existiam representações de navios. Desta visita tirámos notas que existem algures e que esperamos encontrar. Logo que tal suceda não deixaremos de o comunicar, pois poderemos assim confirmar o que a nossa busca de testemunhos que se lhe refiram não tem conseguido até hoje ${ }^{(57)}$. É certo que, mesmo

\footnotetext{
(57) A visita em questão aconteceu por altura da queda do regime monárquico no Iraque, o que ocorreu no Verão de 1958. Os apontamentos foram tomados num caderno constituído por folhas soltas, dobradas, e incluem alguns desenhos.
} 
que assim aconteça, a nossa notícia carecerá de outra ratificação, que continuaremos a procurar. É certo que devemos considerar o princípio jurídico de que o testemunho isolado é um testemunho sem valor, quando não é possível apresentar prova concludente, mas também é certo que a única planta das ruínas do templo do forum de Ossónoba que conhecemos é a do esboço que traçámos em 1969 numa folha de papel de carta.

Vejamos então o que ficou da representação desta embarcação. A proa encontra-se à direita, mostrando um desenho brusco, como se o artista não tivesse espaço suficiente, optando por distorcer a figura. O casco é arredondado, próprio de uma corbita, justificando perfeitamente esta denominação ${ }^{(58)}$. A representação de duas cintas (zosteres) no casco permite considerar que se trata de um navio e não de uma pequena embarcação. Junto da proa são visíveis dois blocos que podem figurar as abitas para fixar a amarra da âncora, elemento frequentemente presente nas imagens de navios. O elemento de forma vagamente triangular que se encontra no limite direito do fragmento pode ser o que resta da cauda de um peixe, pois a hipótese de se tratar do que ficou da vela do artemo, mastro auxiliar inclinado sobre a proa, não parece admissível, na ausência de quaisquer traços do mesmo no mosaico. À esquerda, em direcção à popa, perdida, restam vestígios evidentes da representação do cordame, na forma de duas linhas paralelas, inclinadas sobre a direita, as quais se interrompem abruptamente, o que se deve, com toda a probabilidade, a um restauro do mosaico, como a coloração das tesselas sugere. Na extremidade esquerda, junto a uma dessas linhas, subsiste um pequeno traço que poderá corresponder ao timão do leme.

Considerando o estado do fragmento não é possível, nem conveniente, dizer muito mais. Esperemos que os progressos da investigação permitam

\footnotetext{
(58) O termo corbita (cesto) engloba vários tipos de navios, tendo em comum formas arredondadas, alguma lentidão e dimensões razoáveis, dotados de um quociente de finura reduzido. Os maiores navios deste tipo foram os grandes transportes de trigo da frota anonária africana. Sobre as corbitae: E. Roschach, Corbita, "Dictionnaire des Antiquités Grecques et Romaines", I, 2, Paris, s/d, p.1505 ; Rougé, p.186-189 ; Casson, Ships, p.169-170, 186-189.
} 
descobrir mais alguma coisa sobre a temática marítima e náutica nos mosaicos de Milreu. Esta grande villa, das mais importantes da Lusitânia, foi luxuosamente reconstruída no século IV, integrando possivelmente o património imperial ${ }^{(59)}$. Admitindo esta hipótese cremos ser possível, a partir da forma estilizada dos mapas viários romanos, do tipo da Tábua de Peutinger, que estarão entre as fontes utilizadas pelo Anónimo de Ravena, identificar as ruínas de Milreu com a Statio Sacra referida, entre Balsa e Ossonoba, nesta conhecida obra geográfica da Antiguidade Tardia ${ }^{(60)}$. A importância do porto de Ossonoba, onde poderá ter funcionado uma procuradoria relacionada com a exploração das minas da Lusitânia meridional e onde se achou uma inscrição em honra de um governador da província, Aurelius Ursinus (CIL II $5140=I R C P$ 5), com elevada probabilidade do período final da Tetrarquia, constitui um argumento considerável na atribuição à villa de Milreu da condição de residência imperial, a que o topónimo Statio Sacra corresponde sem qualquer dificuldade ${ }^{(61)}$.

São poucos os navios representados em mosaicos luso-romanos, e de interpretação bastante difícil. Em qualquer dos casos a sua presença parece reflectir, mais do que preocupações de ordem cultural, seguramente a ter em conta, gosto por uma temática marítima, muito em moda de diversas formas e difundida por diferentes canais. A única excepção parece ser a do mosaico da villa de Santa Vitória do Ameixial, onde a cena, fortemente marcada por um modelo norte-africano, conheceu um tratamento que se afasta do cenário habitual, no desenho da embarcação e na forma como as ondas são figuradas através de linhas simples, transmitindo uma agradável impressão de transparência às águas. Como vimos, a análise das características construtivas das

\footnotetext{
(59) Th. Hauschild, Milreu / Estói (Algarve), "Madrider Mitteilungen”, 21, 1980, p.189-219.

${ }^{(60)}$ Rav., IV, 43, 11.

(61) M. Euzennat, Lingots espagnols retrouvés en mer, "Études Classiques", 3, 1971, p.89-98; Ch. Lécrivain, Ratio, Statio, "Dictionnaire des Antiquités Grecques et Romaines", IV, 2, s/d, Paris, p.812-814, 1468-1469.
} 
embarcações permite, nalguns casos identificar, noutros supor, pormenores a relacionar com peculiaridades regionais.

Coincide este Congresso com a data do navigium Isidis, festa que em Março celebrava o final do mare clausum e a reabertura da navegação no mundo romano ${ }^{(62)}$. Por isso, vamos terminar lembrando todos os que navegam ou navegaram por mares a que um dia chamaram seus, honrando-os através do canto de Sophia: Os que avançam de frente para o mar / E nele enterram como uma aguda faca / A proa negra dos seus barcos / Vivem de pouco pão e de luar(63).

${ }^{(62)}$ Apuleio, Met., XI, 3; 15-17. Muitos navios ostentavam o nome da deusa: Luciano, Nav., 5.

${ }^{(63)}$ S. de Mello Breyner, Lusitânia, "Obra Poética”, I, Lisboa, 1992, p.323. 